\title{
$\beta$-Selinene-Rich Essential Oils from the Parts of Callicarpa macrophylla and Their Antioxidant and Pharmacological Activities
}

\author{
Mahesh Chandra ${ }^{1}$, Om Prakash ${ }^{2, *}$ (D), Ravendra Kumar ${ }^{2}$, Rakesh Kumar Bachheti ${ }^{1}$, \\ Brij Bhushan ${ }^{1}$, Mahesh Kumar ${ }^{3}$ and Anil Kumar Pant ${ }^{2}$ \\ 1 Department of Chemistry, Graphic Era University, Dehradun, pin code248 002, Uttarakhand, India; \\ mahesh2747@gmail.com (M.C.); rkbachheti@gmail.com (R.K.B.); brijbushaniitr@gmail.com (B.B.) \\ 2 Department of Chemistry, College of Basic Sciences and Humanities, G.B. Pant University of Agriculture \\ and Technology, Pantnagar, U.S. Nagar, pin code 263145 Uttarakhand, India; \\ ravichemistry.kumar@gmail.com (R.K.); anilpant54@gmail.com (A.K.P.) \\ 3 Department of Medicine, College of Veterinary Sciences, G.B. Pant University of Agriculture and Technology, \\ Pantnagar, U.S. Nagar, pin code 263145 Uttarakhand, India; maheshkumar_epm@rediffmail.com \\ * Correspondence: oporgchem@gmail.com
}

Academic Editors: Eleni Skaltsa and Gerhard Litscher

Received: 24 April 2017; Accepted: 5 July 2017; Published: 10 July 2017

\begin{abstract}
Background: Callicarpa macrophylla (Varbenaceae) is a medicinal shrub and is traditionally used in India, China, and South Asia. Methods: The plant material was collected from lower Himalayan region of Uttarakhand in India. The essential oils from three different aerial parts were analyzed by GC-MS. Antioxidant activity, phenolic assay, and various pharmacological activities were determined by using existing methods which are generally practiced widely. Results: Over 51, 53, and 40 compounds were identified in C. macrophylla leaves essential oil (CMLEO), C. macrophylla pre mature seeds and fruits essential oil (CMEO-I) and C.macrophylla mature seeds and fruits essential oil (CMEO-II), respectively. These oils differ in relative contents of major compounds viz; $\beta$-selinene (37.51\% in CMLEO, 44.66\% in CMEO-I and 57.01\% in CMEO-II), phyllocladene $(9.76 \%$ in CMLEO, 5.80\% in CMEO-I and 12.38\% in CMEO-II), caryophelline oxide (7.34\% in CMLEO, 8.74\% in CMEO-I and 5.0\% in CMEO-II), 9E-epi-caryophelline (6.23\% in CMLEO, 1.27\% in CMEO-I and $3.43 \%$ in CMEO-II), longipinocarvone (4.96\% in CMLEO, 1.17\% in CMEO-I and 2.0\% in CMEO-II), and 1,8-cineole (2.23\% in CMLEO, 3.10\% in CMEO-I and 1.62\% in CMEO-II). The oils exhibited good in vitro antioxidant activity. The maximum activity was found in CMEO-II with $\mathrm{IC}_{50}$ values $7.37 \pm 0.11,11.49 \pm 0.87,14.59 \pm 0.18,15.66 \pm 0.03$, and $17.49 \pm 0.13 \mu \mathrm{L} / \mathrm{mL}$. The essential oils showed qualitative and quantitative diversity in the makeup of essential oils constituents. The oils were found to exhibit anti-inflammatory, analgesic, and antipyretic activity on swiss albino mice compared to the standard drugs, viz; ibuprofen, paracetamol and indomethacin. Conclusion: It is inferred from the study that the plant parts can be used scientifically in traditional systems as folk herbal medicine. Furthermore, we have generated a database for future reference and judicious exploitation of these oils from their natural setting.
\end{abstract}

Keywords: $\beta$-selinene; phylocladene; pharmacology; Callicarpa macropylla; caryophillene oxide

\section{Introduction}

Many plants have been found as a source of natural antioxidants and base components for new drug formation from their essential oils. The Indian Himalayan region is a large repository of medicinal and aromatic plants. In present study, C. macrophylla growing wildly in Uttarakhand Himalaya of 
India was investigated for chemical composition and pharmacological activity of its essential oils. This plant belonging to family Varbenaceae is an erect, stellate-pubescent, perennial shrub, with stems terete and leaves in sub or unequal pairs on $0.3-1.5 \mathrm{~cm}$ long petioles, elliptic-dentate with glandtipped teeth, glabrescent or so above, 10-20 (-25) $\times 4-6(-8) \mathrm{cm}$ while flowers in axillary, 1-3 cm long, peduncled, cymose, corymbose panicles [1]. In this plant, 20 out of 40 species have been reported for their ethno-medical uses. Several members in Chinese and South Asian tradition have been reported as antibiosis, antiphlogosis, and hemostasis drugs [2]. The parts of C. macrophylla have been used to treat many ailments like rheumatism and stomach problems. The bark is used to cure cuts and injuries [3]. As an herbal folk medicine, the seeds and roots of this shrub are used for digestive and abdominal troubles in India [4]. 16 $\alpha$, 17-isopropylidene-3-oxophyllocladane (iso-propylidinocalliterpenone) along with calliterpenone and its monoacetate have been reported in methanol extracts from the residual water extracts left after distillation of the essential oil [5]. Analgesic, anti-pyretic, and anti-inflammatory activities have been reported in aqueous and ethanolic extracts of this plant [6,7]. Terpenoids viz; spathulenol (18.1\%), germacrene B (13.0\%), bicyclogermacrene (11.0\%), globulol (3.3\%), viridiflorol $(2.6 \%)$, a-guaiene $(2.3 \%)$, and g-elemene $(2.0 \%)$ have been reported in the essential oil of $C$. japonica with different chemical makeup from another species, C. americana, growing in Mississippi [8]. We have also reported anti-inflammatory and analgesic activities in aqua-alcoholic leaf extracts of C. macrophylla [9].

Tetracyclic diterpenes, calliterpenone, and calliterpenone-monoacetate from the petroleum ether extract, along with $\beta$-salinene (41.6-29\%) and $\alpha$-salinene (6-1.7\%) in volatile oil of the aerial parts of C. macrophylla have been reported $[10,11]$. In view of its medicinal uses in traditional systems, in the present investigation of different parts of the plant (leaves, pre-mature and mature seeds and fruits) were taken to isolate essential oils and examine the chemo-diversity, antioxidant, and pharmacological activities of this important shrub.

\section{Materials and Methods}

\subsection{Plant Material}

Fresh aerial parts from C. macrophylla were collected during September, October 2011. The plant was taxonomically authenticated by Dr. D.S. Rawat (Assistant Professor \& Plant Taxonomist), Department of Biological Science, G.B. Pant University of Agriculture \& Technology, Pantnagar. The Herbarium specimen was preserved and deposited in the department.

\subsection{Isolation of Essential Oil}

The crushed plant parts were hydro-distilled using Clevenger's type apparatus for over $8 \mathrm{~h}$. The essential oils were extracted by diethyl ether and dried by adding anhydrous $\mathrm{Na}_{2} \mathrm{SO}_{4}$. Removal of solvent yielded $0.20 \%$ ( $w / v$ both in leaves and pre-mature seeds \& fruit) and $0.15 \%(v / w$ in mature seeds \& fruits) of essential oils, respectively.

\subsection{GC Analysis}

Gas chromatographic analysis was done on a Nucon-GC 5765 system interfaced with a flame ionization detector(FID) and capillary colum (DB-5, $30 \mathrm{~m} \times 0.32$ i.d.). The column temperature was induced at $60^{\circ} \mathrm{C}$ for the first $5 \mathrm{~min}$ and then programmed with the RAM of $3{ }^{\circ} \mathrm{C} / \mathrm{min}$ up to $210{ }^{\circ} \mathrm{C}$, and finally isothermally for $10 \mathrm{~min}$. Detector temperature was $210{ }^{\circ} \mathrm{C}$ and $\mathrm{N}_{2}$ was used as carrier gas (flow rate $50 \mathrm{~kg} / \mathrm{cm}^{2}$ ). The injection volume of essential oil used was $0.1 \mu \mathrm{L}$. The percent composition of oil constituents was determined with the help of a FID.

\subsection{GC/MS Analysis}

The essential oils were analyzed using a Shimadzu GC-2010 interfaced, with a Shimadzu GCMS-QP2010 Plus mass selective detector, having omega wax column (30 $\mathrm{m} \times 0.25 \mathrm{~mm}, 0.25 \mu \mathrm{m})$. The column initial oven temperature was $60{ }^{\circ} \mathrm{C}$ and then programmed at $3{ }^{\circ} \mathrm{C} / \mathrm{min}$ to final oven 
temperature $240{ }^{\circ} \mathrm{C}$ with isothermal for $20 \mathrm{~min}$. The injector temperature was $270{ }^{\circ} \mathrm{C}$. Carrier gas used was helium with a flow rate of $2.42 \mathrm{~mL} / \mathrm{min}$ and split ratio of 40:1 For MS detection; electron ionization $(70 \mathrm{eV})$ was used as ionization technique. The ion source temperature was $230{ }^{\circ} \mathrm{C}$ with $280{ }^{\circ} \mathrm{C}$ as the interface temperature. The components were identified by their relative retention times and matching mass spectra with those of standards (main components), from NIST/Wiley library, data of the main system and those published in the literature [12].

\subsection{Antioxidant Assay}

\subsubsection{Reducing Power Activity}

The reducing power was evaluated by the procedures reported earlier [13]. In brief 5, 10, 15, 20, and $25 \mu \mathrm{L}$ of essential oils (EOs) were added in $2.5 \mathrm{~mL}$ of phosphate buffer (200 mM, pH 6.6) and $2.5 \mathrm{~mL}$ of $1 \% \mathrm{~K}_{3}\left[\mathrm{FeCN}_{6}\right]$, followed by $2.5 \mathrm{~mL}$ of $10 \% \mathrm{Cl}_{3} \mathrm{CCOOH}$ after incubation at $50{ }^{\circ} \mathrm{C}$ for $20 \mathrm{~min}$. The content was centrifuged for $10 \mathrm{~min}$ at $650 \mathrm{rpm} .5 \mathrm{~mL}$ of the supernatant was mixed with $5 \mathrm{~mL}$ of distilled water and $1 \mathrm{~mL}$ of $0.1 \% \mathrm{FeCl}_{3}$. The optical density (OD) of the solutions was measured at $700 \mathrm{~nm}$ using UV-spectrophotometer (Thermo scientific, Waltham, MA, USA). The same procedure was followed for controls and standards. BHT, catechin, and gallic acid were used as standard antioxidants.

\subsubsection{Effect on the Chelating Activity of $\mathrm{Fe}^{2+}$}

The procedure is based on the $\mathrm{Fe}^{2+}$ chelating ability of the antioxidant measured calorimetrically at $562 \mathrm{~nm}$ using ferrous ion-ferrozine as a reference complex [14]. $0.1 \mathrm{~mL}$ of $2 \mathrm{mM} \mathrm{FeCl}_{2} \cdot 4 \mathrm{H}_{2} \mathrm{O}$ and $0.2 \mathrm{~mL}$ of $5 \mathrm{mM}$ ferrozine were added to $5-25 \mu \mathrm{L}$ of essential oils followed by methanol to make up the volume to $5 \mathrm{~mL}$. The solutions were homogenized and allowed to react for $10 \mathrm{~min}$. OD was measured at $562 \mathrm{~nm}$. The chelating activity on $\mathrm{Fe}^{2+}$ of EOs were compared with that of EDTA $(0.01 \mathrm{mM})$ and citric acid $(0.025 \mathrm{M})$. The following equation was used to calculate the percent of chelating activity.

$$
\% \text { chelating activity }=\left[1-\mathrm{A}_{\mathrm{t}} / \mathrm{A}_{0}\right] \times 100
$$

$\left(A_{t}=\right.$ absorbance of the sample, $A_{0}=$ absorbance of the control at $\left.562 \mathrm{~nm}\right)$.

\subsubsection{DPPH Radical Scavenging Activity}

The scavenging effect on the DPPH radical was evaluated by following the developed and reported procedures [15]. 5, 10, 15, 20, and $25 \mu \mathrm{L}$ of EOs were mixed with $5 \mathrm{~mL}$ of $0.004 \%$ freshly prepared DPPH solution in $\mathrm{CH}_{3} \mathrm{OH}$. The solutions were placed in the dark for $30 \mathrm{~min}$. OD of the samples, standards, and control were read at $517 \mathrm{~nm}$. BHT, catechin, and gallic acid were used as standards. The percent DPPH radical scavenging activity was calculated by the following equation.

$$
\% \text { DPPH radical scavenging activity }=\left[1-A_{t} / A_{0}\right] \times 100
$$

$\left(A_{t}=\right.$ absorbance of the sample, $A_{0}=$ absorbance of the control at $\left.517 \mathrm{~nm}\right)$.

\subsubsection{NO Radical Scavenging Activity}

Nitric oxide (NO) obtained from sodium nitroprusside (SNP) was measured by the Griess reagent with the composition of $1 \%$ sulfanilamide, $0.1 \%$ naphthylethylenediamine dichloride, and $2.0 \mathrm{~mL}$ orthophosphoric acid. The scavengers of NO competed with oxygen, leading to reduced production of NO. $2 \mathrm{~mL}$ of SNP (10 mM) in phosphate buffer saline (PBS) with pH 7.4 was homogenized with different concentrations $(5-25 \mu \mathrm{L} / \mathrm{mL})$ of EOs dissolved in acetone. The content was incubated at $25{ }^{\circ} \mathrm{C}$ for about $150 \mathrm{~min}$. OD of the pink color developed was read at $546 \mathrm{~nm}$. Ascorbic acid was taken as standard [16]. NO scavenging activity was calculated as:

$$
\% \text { NO scavenging }=\left[1-\mathrm{A}_{\mathrm{t}} / \mathrm{A}_{0}\right] \times 100
$$


$\left(A_{t}=\right.$ absorbance of sample, $A_{0}=$ absorbance of control at $\left.546 \mathrm{~nm}\right)$.

\subsubsection{Super Oxide Radical Scavenging Activity}

In brief $1 \mathrm{~mL}$ nitroblueterazolium $(156 \mathrm{mM}), 1 \mathrm{~mL}$ nicotinamide adenine dinucleotide (468 $\mathrm{mM})$ and $0.1 \mathrm{~mL}$ of phenanzinemethosulphate solution (PMS) in $0.1 \mathrm{M}$ of phosphate buffer solution (pH 7.4) was mixed to various concentrations $(5-25 \mu \mathrm{L})$ of EOs followed by incubation at $25^{\circ} \mathrm{C}$ for $5 \mathrm{~min}$. The OD was measured at $560 \mathrm{~nm}$ against blank containing all reagents except PMS. Ascorbic acid was taken as standard [17]. The \% super oxide radical scavenging activity was calculated as:

$$
\% \text { superoxide radical scavenging }=\left[1-\mathrm{A}_{\mathrm{t}} / \mathrm{A}_{0}\right] \times 100
$$

$\left(A_{t}=\right.$ absorbance of sample, $A_{0}=$ absorbance of control at $\left.560 \mathrm{~nm}\right)$.

\subsubsection{OH Radical Scavenging Activity}

The hydroxyl $(\mathrm{OH})$ scavenging activities of EOs were evaluated by using the developed protocols [17]. Briefly $60 \mu \mathrm{L} \mathrm{FeSO}_{4} .7 \mathrm{H}_{2} 0(1 \mathrm{mM}), 90 \mu \mathrm{L}$ aq. 1,10 phenanthrolein monohydrate $(1 \mathrm{mM}), 2.4 \mu \mathrm{L}(0.2 \mathrm{M})$ phosphate buffer $(\mathrm{pH} 7.8)$ and $150 \mu \mathrm{L}$ of $\mathrm{H}_{2} \mathrm{O}_{2}(0.17 \mathrm{mM})$ was added in $1.5 \mathrm{~mL}$ of EOs ( $5-25 \mu \mathrm{L})$. OD was measured at $560 \mathrm{~nm}$ for samples control and standards (ascorbic acid). The $\% \mathrm{OH}$ scavenging activity was calculated as:

$$
\% \mathrm{OH} \text { scavenging }=\left[1-\mathrm{A}_{0} / \mathrm{A}_{\mathrm{t}}\right] \times 100
$$

$\left(A_{t}=\right.$ absorbance of sample, $A_{0}=$ absorbance of the control at $\left.560 \mathrm{~nm}\right)$.

\subsection{Evaluation of Pharmacological Activities}

Permission from the institutional ethical committee (Registration No. 330/CPCSEA, Dated, 1 Marth 2001, however the experiments were conducted in the month of December 2012) was taken prior to execute the experiments. Swiss albino mice were procured from the Lab Animal Division of the Central Drug Research Institute, Lucknow, U.P. in India. The animals were randomly divided into eleven groups with six mice in each and were kept under standard laboratory conditions. Three concentrations $(5 \%, 10 \%$, and $20 \%$ ) of EOs were given orally with the dose level of $10 \mathrm{~mL} / \mathrm{kg}$ body weight. All the concentrations of EOs were separately triturated by addition of small amount of tween-20 and saline water to make the final volume of $10 \mathrm{~mL}$. Ibuprofen, indomethacin, and paracetamol were used as standard drugs and saline water as control.

\subsection{Anti-Inflammatory Activity}

\subsubsection{Carrageenan-Induced Paw Edema}

The anti-inflammatory activity of EOs were evaluated according to the protocols reported [18]. Briefly, edema was induced by injecting carrageenan $(0.1 \mathrm{~mL}, 1 \% \mathrm{w} / \mathrm{v}$ in saline $)$ in the sub plantar tissue of the right hind paw of mice. The ninth group was given EOs 5, 10, and $20 \%$ as $10 \mathrm{~mL} / \mathrm{kg}$ body weight, group ten was given ibuprofen $(40 \mathrm{mg} / \mathrm{kg} \mathrm{b}$. wt.), while group eleven received only saline water. The paw volumes were measured plethysmometrically at 1,3 , and $24 \mathrm{~h}$ after the carrageenan injection. It has been reported that formation of edema is a result of synergism between inflammatory mediators which provoke vascular permeability and mediate the blood flow [19]. The decrease in the paw volume in comparison to control was taken as anti-inflammatory effect.

\subsubsection{Formaldehyde-Induced Inflammatory Activity}

This activity of the EOs were studied in HCHO induced arthritis. Briefly, $0.1 \mathrm{~mL} \mathrm{HCHO} \mathrm{(1 \% )}$ solution was injected in the right hind paw of the mice [20]. The EOs were administered orally every 
day in the morning during tenure (10 days) of experiments. Ibuprofen suspension ( $40 \mathrm{mg} / \mathrm{kg} \mathrm{b}$. wt.) was used as standard anti-inflammatory drug. The control group was given only saline water. Paw volumes of all the mice were measured plethysmometrically.

\subsection{Analgesic Activity}

Acetic Acid-Induced Abdominal Writhing Test

In this activity, the animals were treated with glacial acetic acid intraperitoneally to induce pain sensation [21]. After $1 \mathrm{~h}, 0.2 \mathrm{~mL}$ of EOs, ibuprofen $(40 \mathrm{mg} / \mathrm{kg} \mathrm{b}$. wt.), and saline water were orally administered. The numbers of writhings were counted for $30 \mathrm{~min}$ in each mouse. The reduction of writhing in mice by ibuprofen was compared and the percentage of pain protection was calculated using the following formula:

$$
\% \text { writhing }=(\mathrm{T} / \mathrm{C}) \times 100 ; \% \text { Inhibition }=(\mathrm{C}-\mathrm{T} / \mathrm{C}) \times 100
$$

$\mathrm{T}=$ treatments (group $\mathrm{I}-\mathrm{IX}) ; \mathrm{C}=\mathrm{Control}$ saline group $(\mathrm{X})$.

\subsection{Antipyretic Activity}

To evaluate antipyretic activity pyrexia was induced in mice by subcutaneous injection of $20 \%$ brewer's yeast (Sacchromyces cerevisiae) $(10 \mathrm{mg} / \mathrm{kg} \mathrm{b}$. wt.) as per the reported protocol [22]. The mice were maintained in a quiet laboratory environment for $18 \mathrm{~h}$ in order to raise body temperature. At the 19th hour, the rectal temperature was recorded. After $18 \mathrm{~h}$ of injection of yeast, immediately essential oils $(5 \%, 10 \%$ and $20 \%)$, and paracetamol $(33 \mathrm{mg} / \mathrm{kg} \mathrm{b}$. wt.) were administered orally. The control group was given only $0.2 \mathrm{~mL}$ normal saline. The temperature was monitored at hourly intervals in all the mice up to $3 \mathrm{~h}$ and the percentage reduction in rectal temperature was calculated by considering the total fall in temperature to normal level as $100 \%$.

$$
\% \text { reduction }=\{(B-C / B-A) \times 100\}
$$

$\mathrm{A}=$ normal temperature $\mathrm{B}=$ Pyrexia temperature $\mathrm{C}=$ temp at hourly interval

\subsection{Assessment of Toxicity}

In order to evaluate the toxic effect of essential oils, different doses $(40 \%, 60 \%$, and $80 \%)$ at $10 \mathrm{~mL} / \mathrm{kg}$ body weight were given to experimental animals. For toxic effect of drug under experiment, the behavioral changes were recorded for $24 \mathrm{~h}$ and the numbers of deaths if any were recorded up to $48 \mathrm{~h}$.

\subsection{Statistical Analysis}

The experimental data generated were represented as mean \pm S.E and the results were analyzed using one way analysis of variance. The value of $p<0.05$ were considered to be statistically significant.

\section{Results and Discussion}

Over 40-53 compounds were identified in CMLEO, CMEO-I, and CMEO-II which contributed to $96.55 \%, 94.56 \%$, and $95.35 \%$ of the total oil, respectively. The constituents identified in CMLEO, were $\beta$-selinene $(37.51 \%)$, phyllocladene $(9.76 \%)$, caryophelline oxide $(7.34 \%)$, caryophelline-9-epi (E) $(6.23 \%)$, longipinocarvone $(4.96 \%), \beta$-caryophelline $(3.26 \%)$, juniper camphor $(3.13 \%)$, vulgarone $(2.92 \%), 1,8$-cineole $(2.23 \%), \alpha$-muurolol $(1.76 \%)$, and sphathulenol (1.06\%) (Table 1). In CMEO-I, the identified constituents $\beta$-selinene $(44.66 \%)$, caryophelline oxide $(8.74 \%)$, phyllocladene $(5.80 \%)$, 1,8-cineole (3.10\%), juniper camphor (3.03\%), longicamphenylone $(3.08 \%)$, aromadandrene $(2.14 \%)$, sphathulenol (2.10\%), caryophelline-9-epi(E) (1.27\%), longipinocarvone (1.17\%), $\beta$-pinene $(1.07 \%)$, and 
vulgarone $(1.02 \%)$ were major compounds along with other minor ones (Table 1$)$. $\beta$-selinene $(57.01 \%)$, phyllocladene $(12.38 \%)$, caryophelline oxide $(5.0 \%)$, 9E-epi-caryophelline $(3.43 \%), \beta$-pinene $(2.32 \%)$ longipinocarvone $(2.0 \%), 1,8$-cineole $(1.62 \%), \beta$-caryophelline $(1.84 \%)$, vulgarone $(0.40 \%)$, sphathulenol $(0.30 \%)$, and aromadandrene $(0.19 \%)$ were identified in CMEO II (Table 1$)$.

$\beta$-Salinene has been found as a major compound in all the EOs. The oils also showed diversity both in qualitative and quantitative makeup of essential oils. CMEO-I contained longicamphnylone $(3.08 \%)$, 4-camphenylbutan-2-one $(0.80 \%)$ cedren-13-ol $(0.52 \%)$, nopinone $(0.50 \%)$, hexanoic acid $(0.47 \%)$, terpinen-4-ol $(0.43 \%)$, bornyl acetate $(0.42 \%)$, and leden oxide-I $(0.40 \%)$ which were absent in other oils. Muurolene-14-oxy- $\alpha(2.50 \%), \alpha$-muurolol (1.76\%), $\beta$-copaen-4- $\alpha$-ol $(1.03 \%)$, globulol $(0.42 \%), \beta$-oplopenone $(0.33 \%)$ etc were found only in CMLEO, while 5 -octen-2-one $(0.53 \%), \beta$-ocimene $(0.31 \%), \alpha$-pinene $(0.40 \%)$, and khusinol $(0.10 \%)$ were identified only in CMEO-II (Table 1$)$.

Table 1. Essential oil composition from different parts of Callicarpa macropylla.

\begin{tabular}{|c|c|c|c|c|c|}
\hline \multirow{2}{*}{ S.N. } & \multirow{2}{*}{ Compounds Name } & \multirow{2}{*}{ KI/RI } & \multicolumn{3}{|c|}{ FID \% } \\
\hline & & & CMLEO & CMOE-I & CMEO-II \\
\hline 1 & hex-2E-enal & 850 & 0.20 & - & - \\
\hline 2 & $\alpha$-pinene & 933 & 0.06 & - & 0.40 \\
\hline 3 & $\beta$-pinene & 943 & 0.53 & 1.07 & 2.32 \\
\hline 4 & 1-octene-3one & 943 & 0.02 & 0.12 & 0.02 \\
\hline 5 & 3-octanone & 952 & 0.10 & 0.12 & 0.06 \\
\hline 6 & banzaldehide & 960 & 0.14 & - & - \\
\hline 7 & sabinene & 972 & 0.17 & 0.40 & 0.25 \\
\hline 8 & hexanoic acid & 979 & - & 0.47 & - \\
\hline 9 & myrcene & 991 & - & - & 0.04 \\
\hline 10 & hex-3Z-ethyl acetate & 1008 & 0.01 & - & - \\
\hline 11 & p-cymene & 1025 & 0.13 & 0.41 & 0.14 \\
\hline 12 & limonene & 1030 & - & 0.15 & 0.12 \\
\hline 13 & 1,8-cineole & 1032 & 2.23 & 3.10 & 1.62 \\
\hline 14 & $\beta$-ocimene & 1046 & - & - & 0.31 \\
\hline 15 & 2-nonanone & 1052 & 0.02 & - & - \\
\hline 16 & trans-2-octenal & 1067 & - & 0.27 & - \\
\hline 17 & cis linalool oxide & 1069 & - & 0.21 & - \\
\hline 18 & trans linalool oxide & 1086 & - & 0.15 & - \\
\hline 19 & linalool & 1101 & 0.20 & 0.86 & - \\
\hline 20 & nopinone & 1139 & - & 0.50 & - \\
\hline 21 & sabina ketone & 1154 & 0.03 & - & - \\
\hline 22 & pinocarvone & 1164 & - & 0.64 & 0.45 \\
\hline 23 & terpinen-4-ol & 1180 & - & 0.43 & - \\
\hline 24 & myrtenal & 1197 & 0.23 & 0.74 & 0.20 \\
\hline 25 & 1-butyryl-1,2,3,6-tetrahydropyridine & 1249 & 0.05 & & \\
\hline 26 & 3,9-dodecadiyn & 1249 & 0.37 & - & - \\
\hline 27 & bornyl acetate & 1285 & - & 0.42 & - \\
\hline 28 & leden oxide (I) & 1293 & - & 0.40 & - \\
\hline 29 & myrtenal acetate & 1326 & - & 0.19 & - \\
\hline 30 & $\alpha$-copaene & 1375 & 0.35 & - & 0.27 \\
\hline 31 & $\beta$-elemene & 1390 & 0.98 & 0.82 & 0.61 \\
\hline 32 & $\beta$-cubebene & 1392 & 0.10 & 0.09 & 0.48 \\
\hline 33 & $\alpha$-gurjunene & 1406 & 0.50 & 0.95 & 0.15 \\
\hline 34 & nopyl acetate & 1413 & - & 0.26 & - \\
\hline 35 & $\beta$-caryophelline & 1424 & 3.26 & - & 1.84 \\
\hline 36 & (E) caryophellene & 1424 & 0.44 & - & 0.11 \\
\hline 37 & aromadandrene & 1438 & - & 2.14 & 0.19 \\
\hline 38 & 4-camphenylbutan-2-one & 1451 & - & 0.80 & - \\
\hline 39 & $\alpha$-humulene & 1454 & - & - & 0.14 \\
\hline 40 & aromadendrene oxide II & 1462 & 0.43 & 0.46 & 0.25 \\
\hline 41 & 9E-epi-caryophelline & 1464 & 6.23 & 1.27 & 3.43 \\
\hline 42 & $\alpha$-selinene & 1474 & 0.26 & & \\
\hline 43 & $\alpha$-cubebene & 1480 & 0.11 & - & - \\
\hline 44 & ar-curcumene & 1480 & 0.19 & 0.10 & 0.14 \\
\hline 45 & $\beta$-selinene & 1492 & 37.51 & 44.66 & 57.01 \\
\hline
\end{tabular}


Table 1. Cont

\begin{tabular}{|c|c|c|c|c|c|}
\hline \multirow{2}{*}{ S.N. } & \multirow{2}{*}{ Compounds Name } & \multirow{2}{*}{$\mathrm{KI} / \mathrm{RI}$} & \multicolumn{3}{|c|}{ FID \% } \\
\hline & & & CMLEO & CMOE-I & CMEO-II \\
\hline 46 & amorphene & 1502 & 0.41 & - & - \\
\hline 47 & perhydropyrene & 1502 & & 0.37 & \\
\hline 48 & caryophelline oxide & 1507 & 7.34 & 8.74 & 5.0 \\
\hline 49 & $\delta$-cadinine & 1518 & 0.85 & 0.41 & 0.59 \\
\hline 50 & trans-calamene & 1527 & 0.35 & 0.15 & 0.31 \\
\hline 51 & globulol & 1530 & 0.42 & - & - \\
\hline 52 & Z- $\alpha$-bisaboline epoxide & 1531 & & 0.21 & \\
\hline 53 & $\alpha$-agarofuron & 1548 & - & 0.40 & - \\
\hline 54 & (E)-nerolidol & 1561 & - & 0.20 & - \\
\hline 55 & longicamphenylone & 1563 & - & 3.08 & - \\
\hline 56 & longipinocarvone & 1569 & 4.96 & 1.17 & 2.0 \\
\hline 57 & sphathulenol & 1576 & 1.06 & 2.10 & 0.30 \\
\hline 58 & $\beta$-copaen- $4 \alpha$-ol & 1590 & 1.03 & - & - \\
\hline 59 & trans longipinocarveol & 1590 & 0.63 & 0.71 & - \\
\hline 60 & fokienol & 1596 & 0.38 & 0.31 & - \\
\hline 61 & salvial-4 (14)-en-1-one & 1596 & 0.73 & - & - \\
\hline 62 & $\beta$-oplopanone & 1607 & 0.33 & & \\
\hline 63 & humulene epoxide II & 1613 & 0.21 & - & - \\
\hline 64 & Z-3-hexadecane-7-yne & 1637 & - & 0.31 & - \\
\hline 65 & solavetivone & 1645 & 0.99 & 0.30 & 0.40 \\
\hline 66 & cedren-13-ol & 1646 & - & 0.52 & - \\
\hline 67 & vulgarone & 1649 & 2.92 & 1.02 & 0.40 \\
\hline 68 & $\alpha$-muurolol & 1651 & 1.76 & - & - \\
\hline 69 & cadalene & 1677 & - & 0.32 & - \\
\hline 70 & khusinol & 1679 & - & - & 0.10 \\
\hline 71 & juniper camphor & 1696 & 3.13 & 3.03 & - \\
\hline 72 & cis-lanceol & 1760 & 0.12 & - & - \\
\hline 73 & 14 -oxy $\alpha$-muurolene & 1767 & 2.50 & - & - \\
\hline 74 & phyllocladene & 1789 & 9.76 & 5.80 & 12.38 \\
\hline 75 & cupressene & 1880 & - & 0.47 & - \\
\hline 76 & 5-octen-2-one & 1932 & & & 0.53 \\
\hline 77 & androsta-4,16-dien-3-one & 1933 & 0.71 & 0.50 & 0.70 \\
\hline 78 & androsta-3,5-dien-7-one & 1933 & 0.55 & 0.26 & 0.32 \\
\hline 79 & 6-androstanone & 1940 & & & 0.13 \\
\hline 80 & n-hexadecanoic acid & 1977 & & & 0.43 \\
\hline 81 & 9Z,12Z,15Z-octadecatrien-1-ol & 2077 & 0.20 & & \\
\hline 82 & pimara-7,15-dien-3-one & 2097 & 0.36 & 0.16 & 0.24 \\
\hline 83 & thunbergol & 2211 & - & 0.98 & 0.23 \\
\hline \multirow[t]{2}{*}{84} & andrographolide & 2944 & & 0.84 & 0.74 \\
\hline & Total & & 96.55 & 94.56 & 95.35 \\
\hline
\end{tabular}

S.N. = Serial number.:, KI/RI= Kovat indicest/retention indices.

\subsection{Antioxidant Assay}

\subsubsection{Reducing Power}

The essential oils showed good reducing activity as the function of concentration compared to standard antioxidants (BHT, catechin, and gallic acid). CMEO-II showed the highest reducing property of the extracts (Figure 1). 


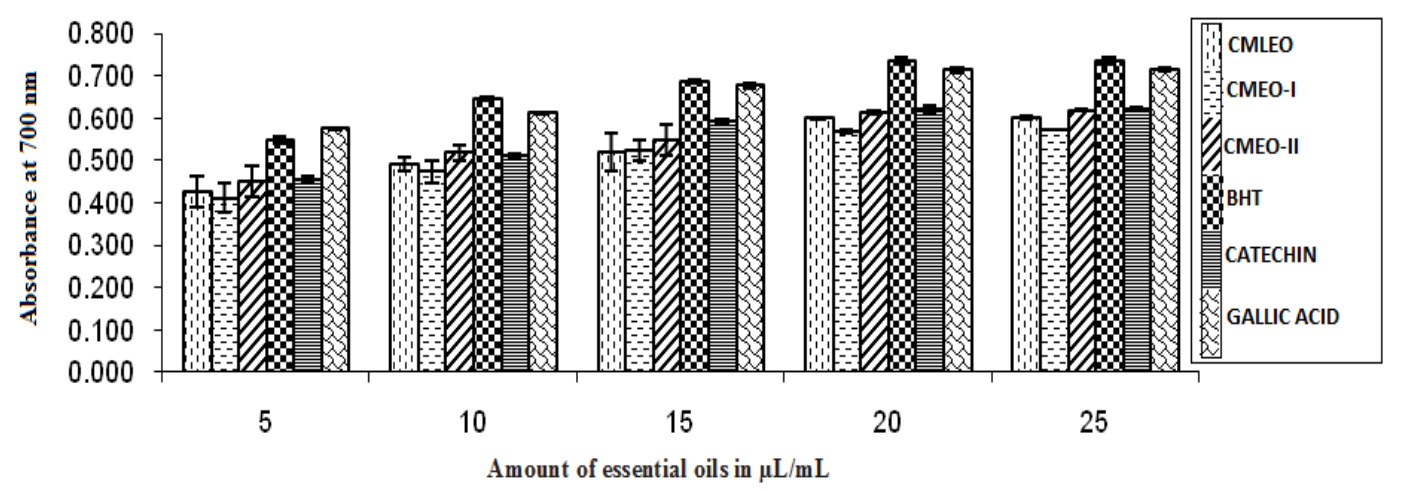

Figure 1. Reducing power activity.

\subsubsection{Ability of Chelating $\mathrm{Fe}^{2+}$ Ion}

As shown in Figure 2, all the EOs revealed good $\mathrm{Fe}^{2+}$ chelating with maximum chelating values of $63.82 \%$ recorded for CMEO-II, at $25 \mu \mathrm{L} / \mathrm{mL}$ of dose level compared to standard antioxidants.

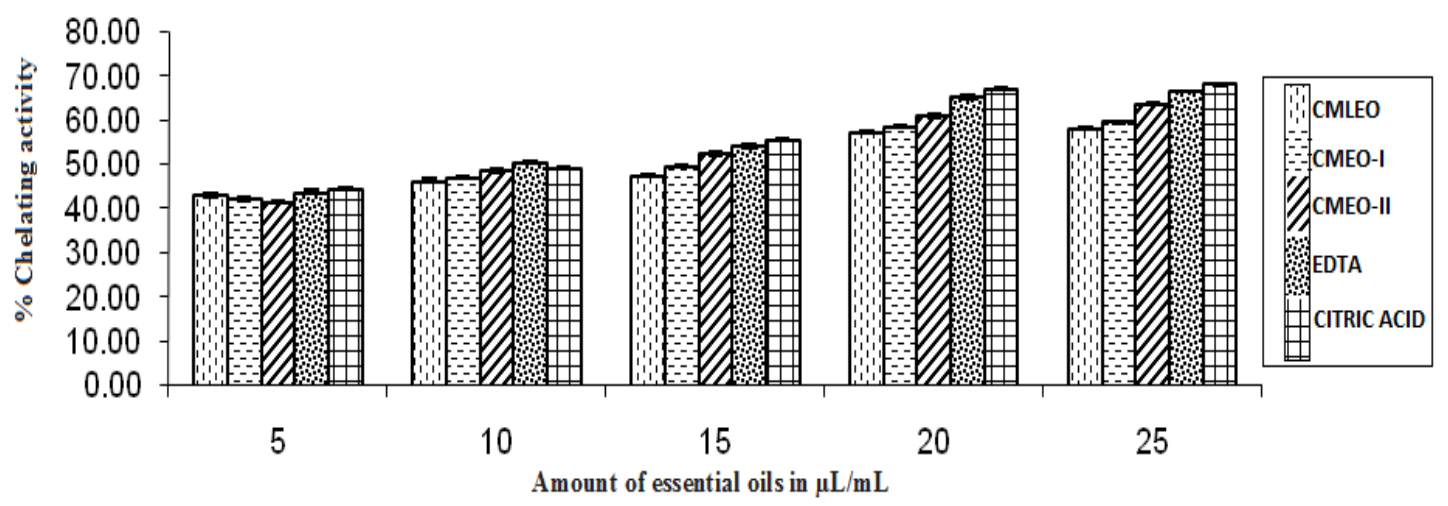

Figure 2. Chelating activity.

\subsubsection{DPPH Radical Scavenging Activity}

The EO showed good to moderate DPPH radical scavenging activity. CMEO-II was a better DPPH radical scavenger than CMLEO and CMEO-I, compared to standard antioxidant viz. BHT, catechin, and gallic acid (Figure 3). DPPH scavenging activity was observed between 55.67-62.63\% at highest concentration $(25 \mu \mathrm{L})$ among the oils. However, the standard showed slightly stronger activity in the range of $69.39-73.58 \%$.

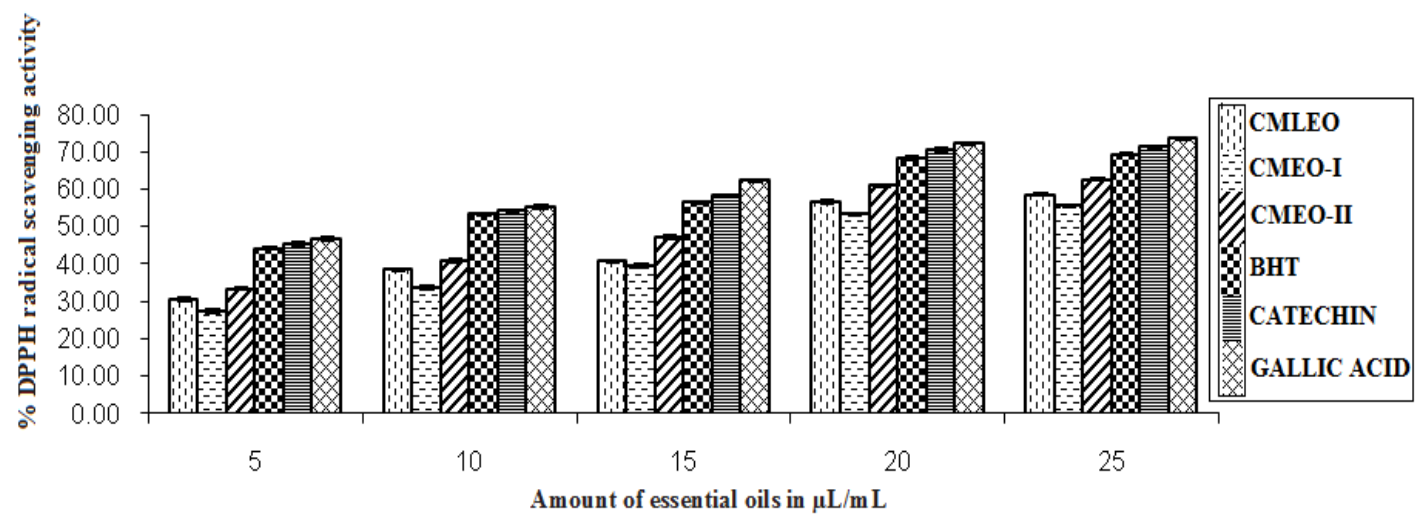

Figure 3. DPPH radical scavenging activity. 


\subsubsection{Superoxide Radical Scavenging Activity}

CMEO-II, CMEO-I, and CMLEO exhibited good superoxide scavenging activity with maximum at higher concentration. CMLEO-II revealed highest scavenging activity $(56.98 \pm 0.630 \%)$ followed by CMLEO (56.49 $\pm 0.412 \%)$ and CMEO-I ( $53.13 \pm 0.724 \%)$, respectively, as compared to ascorbic acid $(60.76 \pm 0.313 \%)$ (Figure 4$)$.

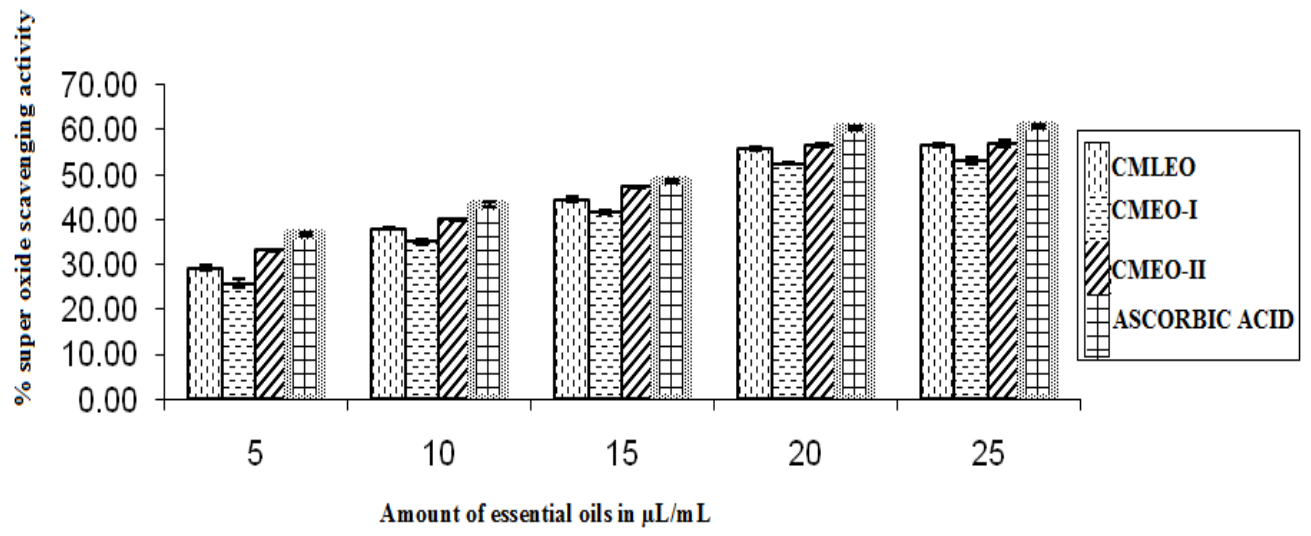

Figure 4. Super oxide scavenging activity.

\subsubsection{NO Radical Scavenging Activity}

The EOs were good NO radical scavengers but moderate in comparison to the standard, ascorbic acid. CMEO-II was the strongest NO scavenger among the oils and scavenged $43.51 \pm 0.329$ $70.68 \pm 0.115 \%$ NO radical from $5 \mu \mathrm{L}$ to $25 \mu \mathrm{L}$ (Figure 5).

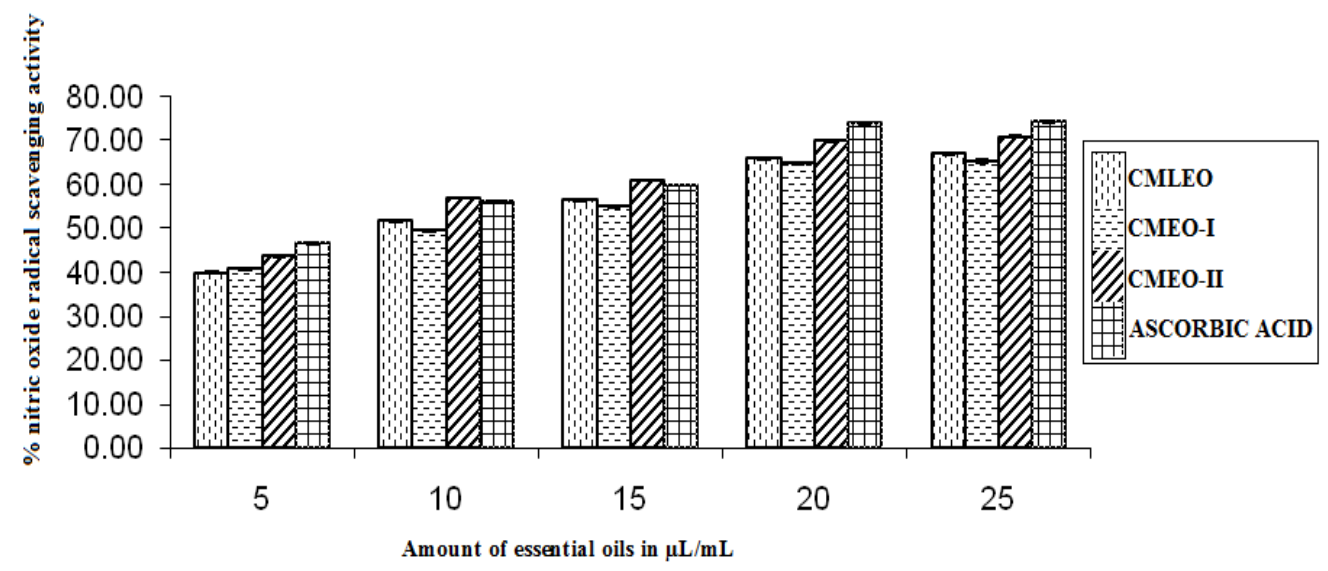

Figure 5. Nitric oxide radical scavenging activity.

\subsubsection{OH Radical Scavenging Activity}

The oils exhibited $\mathrm{OH}$ radical scavenging in a dose-dependent manner similar to DPPH, NO, and superoxide methods. Maximum scavenging activity was observed at the concentration level of $25 \mu \mathrm{L}$ in ascorbic acid (68.48 $\pm 0.708 \%)$ followed by CMEO-II (64.4 $\pm 0.900 \%)$, CMLEO (61.22 $\pm 0.340 \%)$, and CMEO-I (57.03 $\pm 0.520 \%)$, respectively (Figure 6). 


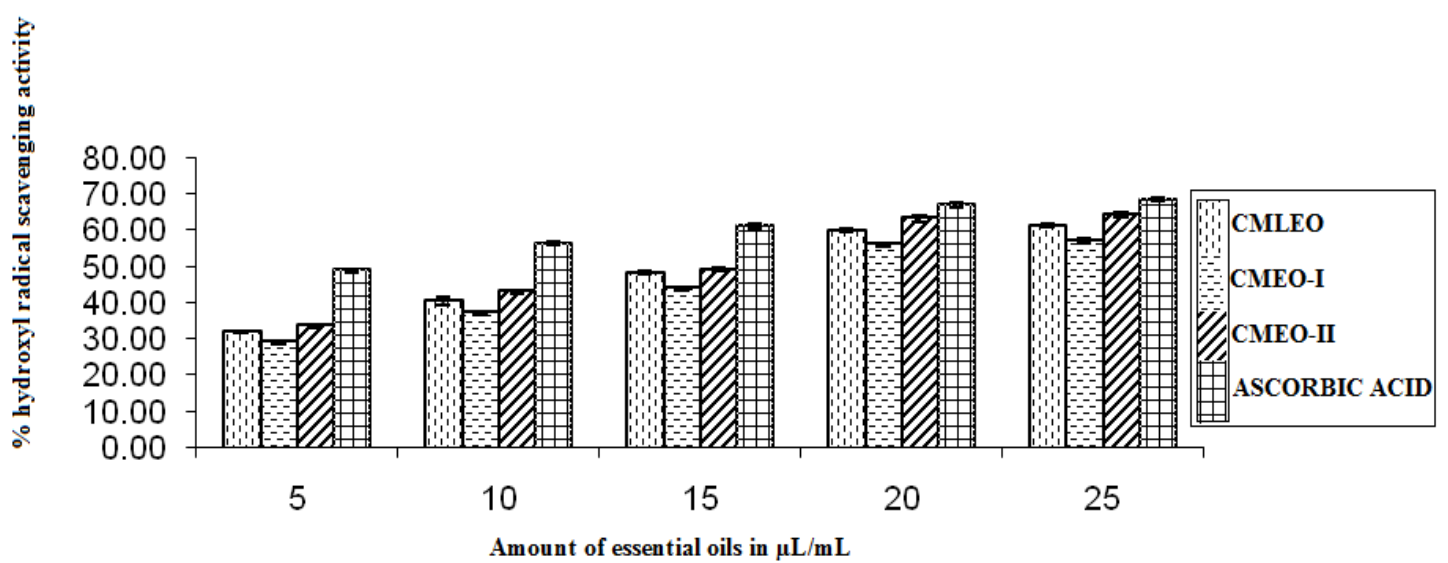

Figure 6. Hydroxyl radical scavenging activity.

The results obtained as $\mathrm{IC}_{50}$ values for scavenging and chelating activity of the EOs indicated their efficiency against oxidative stress as well as free radicals. CMEO-II showed the minimum $\mathrm{IC}_{50}$ value in all the activity tests among the oils and the highest antioxidant activity, but was moderate in comparison to the standards (Table 2). The $\mathrm{IC}_{50}$ values for chelating activity were found in the order of EDTA $\left(\mathrm{IC}_{50}=9.27 \pm 0.11 \mu \mathrm{g} / \mathrm{mL}\right)$, followed by citric acid $\left(\mathrm{IC}_{50}=9.42 \pm 0.95 \mu \mathrm{g} / \mathrm{mL}\right)$, CMEO-II $\left(\mathrm{IC}_{50}=11.49 \pm 0.87 \mu \mathrm{L} / \mathrm{mL}\right)$, CMEO-I $\left(\mathrm{IC}_{50}=13.42 \pm 0.17 \mu \mathrm{L} / \mathrm{mL}\right)$, and CMLEO $\left(\mathrm{IC}_{50}\right.$ $=14.38 \pm 0.27 \mu \mathrm{L} / \mathrm{mL}$ ). The DPPH radical is a highly reactive species and used for evaluation of free radical scavenging activity of antioxidants. It accepts an electron and a hydrogen to become a stable diamagnetic molecule $[18,19]$. The scavenging effect of the EOs and standards with the DPPH radical were observed in the following order: gallic acid $\left(\mathrm{IC}_{50}=7.95 \pm 0.11 \mu \mathrm{g} / \mathrm{mL}\right)>$ catechin $\left(\mathrm{IC}_{50}=8.18 \pm 0.11 \mu \mathrm{g} / \mathrm{mL}\right)>$ BHT $(8.55 \pm 0.10 \mu \mathrm{g} / \mathrm{mL})>$ CMEO-II $\left(\right.$ IC $\left._{50}=15.66 \pm 0.03 \mu \mathrm{L} / \mathrm{mL}\right)>$ CMLEO $\left(\mathrm{IC}_{50}=18.35 \pm 0.18 \mu \mathrm{L} / \mathrm{mL}\right)>$ CMEO-I $\left(\mathrm{IC}_{50}=20.19 \pm 0.11 \mu \mathrm{L} / \mathrm{mL}\right)$. It has been reported earlier that the plant-derived products mitigate the harmful effects produced by nitric oxide radicals in human body $[20,21]$. In the present investigation, the level of nitric oxide was decreased with increased concentration of the EOs. CMEO-II had the strongest anti-radical activity with the $\mathrm{IC}_{50}$ value $7.37 \pm 0.11 \mu \mathrm{L} / \mathrm{mL}$, which was comparable to ascorbic acid (Table 2). It has been reported that nitric oxide production becomes high in tumor tissues, plasma, and other physiological and pathological processes [23]. The superoxide anion is a forerunner of reactive oxygen species and produces destructive effects to cellular systems [24]. Photochemically generated $\mathrm{O}_{2}$ ' reduces to NBT and forms blue formazan [25]. It has been observed that inhibition of formation of the blue formazan is a function of the concentration of the essential oils, which were found to be efficient scavengers of superoxide radicals and their activity were moderate compared to ascorbic acid. Damage to the adjacent biomolecules by the most reactive hydroxyl radical has been reported along with oxidative damage to DNA, lipids, and proteins $[26,27]$. The present study reveals the maximum hydroxyl radical scavenging effect of essential oils at the concentration level of $25 \mu \mathrm{L} / \mathrm{mL}$.

All the essential oils had low amounts of phenolic compounds but showed good antioxidant activity. The diversified mono- and sesquiterpenoids present in the complex mixture of essential oils might be responsible for the good antioxidant activity because of synergetic effects of the constituents. This can be evidenced by a report which says that antioxidant capacity is affected by other bioactive compounds and could involve synergistic effects [28]. 
Table 2. Antioxidant properties in terms of $\mathrm{IC}_{50}$ values in essential oils from different areal parts of C. macrophylla.

\begin{tabular}{|c|c|c|c|c|c|c|c|c|c|c|c|c|}
\hline \multirow{4}{*}{ Extracts } & \multicolumn{10}{|c|}{$\left(\mathrm{IC}_{50}\right.$ in $\left.(\mu \mathrm{L} / \mu \mathrm{g}) / \mathrm{mL}\right) / \mathrm{R}^{2}$} & \multicolumn{2}{|c|}{ \% Absorbance (Reducing Power) } \\
\hline & \multicolumn{8}{|c|}{ Radical scavenging Activities } & \multirow{2}{*}{\multicolumn{2}{|c|}{ Chelating Activity }} & \multirow{3}{*}{$\begin{array}{c}\text { At lower Dose } \\
\text { Level } \\
(5 \mu \mathrm{L} / \mu \mathrm{g}) / \mathrm{mL}\end{array}$} & \multirow{3}{*}{$\begin{array}{c}\text { At Higher Dose } \\
\text { Level } \\
(25 \mu \mathrm{L} / \mu \mathrm{g}) / \mathrm{mL}\end{array}$} \\
\hline & \multicolumn{2}{|c|}{ DPPH Scavenging } & \multicolumn{2}{|c|}{ NO scavenging } & \multicolumn{2}{|c|}{ Super Oxide Scavenging } & \multicolumn{2}{|c|}{ OH Scavenging } & & & & \\
\hline & $\mathrm{IC}_{50}$ & $R^{2}$ & $\mathrm{IC}_{50}$ & $R^{2}$ & $\mathrm{IC}_{50}$ & $R^{2}$ & $\mathrm{IC}_{50}$ & $R^{2}$ & $\mathrm{IC}_{50}$ & $R^{2}$ & & \\
\hline CMLEO & $18.35 \pm 0.18$ & $0.933 \pm 0.003$ & $10.61 \pm 0.02$ & $0.941 \pm 0.000$ & $18.58 \pm 0.19$ & $0.956 \pm 0.006$ & $16.06 \pm 0.16$ & $0.963 \pm 0.006$ & $14.38 \pm 0.27$ & $0.913 \pm 0.009$ & $0.426 \pm 0.004$ & $0.602 \pm 0.000$ \\
\hline CMEO-I & $20.29 \pm .11$ & $0.960 \pm 0.06$ & $11.18 \pm 0.06$ & $0.95 \pm 0.004$ & $20.79 \pm 0.30$ & $0.954 \pm 0.005$ & $18.59 \pm 0.25$ & $0.960 \pm 0.006$ & $13.42 \pm 0.17$ & $0.950 \pm 0.004$ & $0.411 \pm 0.003$ & $0.573 \pm 0.000$ \\
\hline CMEO-II & $15.66 \pm 0.03$ & $0.961 \pm 00.005$ & $7.37 \pm 0.11$ & $0.922 \pm 0.002$ & $17.49 \pm 0.13$ & $0.954 \pm 0.015$ & $14.59 \pm 0.18$ & $0.956 \pm 0.016$ & $11.49 \pm 0.87$ & $0.979 \pm 0.006$ & $0.450 \pm 0.004$ & $0.418 \pm 0.000$ \\
\hline BHT & $8.55 \pm 0.10$ & $0.947 \pm 0.005$ & NA & NA & NA & NA & NA & NA & NA & NA & $0.55 \pm 0.008$ & $0.735 \pm 0.009$ \\
\hline Catechin & $8.18 \pm 0.11$ & $0.950 \pm 0.004$ & NA & NA & NA & NA & NA & NA & NA & NA & $0.455 \pm 0.006$ & $0.623 \pm 0.004$ \\
\hline Gallic Acid & $7.95 \pm 0.11$ & $0.964 \pm 0.004$ & NA & NA & NA & NA & NA & NA & NA & NA & $0.575 \pm 0.003$ & $0.715 \pm 0.003$ \\
\hline Ascorbic acid & NA & NA & $7.72 \pm 0.19$ & $0.942 \pm 0.002$ & $15.03 \pm 0.13$ & $0.951 \pm 0.007$ & $11.22 \pm 0.30$ & $0.960 \pm 0.017$ & NA & NA & NA & NA \\
\hline EDTA & NA & NA & NA & NA & NA & NA & NA & NA & $9.27 \pm 0.11$ & $0.955 \pm 0.003$ & NA & NA \\
\hline Citric Acid & NA & NA & NA & NA & NA & NA & NA & NA & $9.42 \pm 0.95$ & $0.981 \pm 0.021$ & NA & NA \\
\hline
\end{tabular}

$R^{2}=$ linear regression factor, $\mathrm{NA}=$ not applicable. 


\subsection{Anti-Inflammatory Activity}

\subsubsection{Mice Paw Edema (Carrageenan-Induced)}

A gradual increase in carrageenan-induced hind paw edema volume of mice in the control and sample groups was observed. However, in CMEO-II, CMLEO, CMEO-I, and standard drug treated groups, a significant reduction in the volume of edema was observed (Table 3). Other concentrations of oils showed moderate activity in comparison to the standard drug. The inhibitory effect of the oils was observed to be the highest with a dose level of $20 \%$ oils at $24 \mathrm{~h}$, as $21.16 \%$ in CMEO-II, $17.78 \%$ in CMLEO, and $16.30 \%$ in CMEO-I, whereas ibuprofen produced a $37.17 \%$ reduction in the same experimental conditions (Table 3).

Table 3. Effect of essential oils from C. macrophylla on carrageenan-induced paws edema.

\begin{tabular}{|c|c|c|c|c|c|c|c|}
\hline \multirow{2}{*}{ Group } & \multirow{2}{*}{ Treatment } & \multirow{2}{*}{ Doses $(0.2 \mathrm{~mL})$} & \multicolumn{3}{|c|}{ Paw Volume (in $\mathrm{mm}^{3}$ ) } & \multicolumn{2}{|c|}{$\%$ Inhibition } \\
\hline & & & $\mathbf{O h}$ & $4 \mathrm{~h}$ & $24 \mathrm{~h}$ & $4 \mathrm{~h}$ & $24 \mathrm{~h}$ \\
\hline I & CMLEO & $5 \%$ & $2.34 \pm 0.01$ & $2.29 \pm 0.02^{b}$ & $2.23 \pm 0.02^{a b}$ & 2.14 & 4.7 \\
\hline II & CMLEO & $10 \%$ & $2.31 \pm 0.03^{\mathrm{a}}$ & $2.21 \pm 0.02^{\mathrm{ab}}$ & $2.12 \pm 0.01^{\mathrm{ab}}$ & 4.33 & 8.23 \\
\hline III & CMLEO & $20 \%$ & $2.25 \pm 0.02^{\mathrm{ab}}$ & $2.05 \pm 0.02^{\mathrm{ab}}$ & $1.85 \pm 0.03^{\mathrm{ab}}$ & 8.89 & 17.78 \\
\hline IV & CMEO-II & $5 \%$ & $2.29 \pm 0.01^{\mathrm{a}}$ & $2.19 \pm 0.02^{\mathrm{ab}}$ & $2.14 \pm 0.03^{a b}$ & 4.37 & 6.55 \\
\hline $\mathrm{V}$ & CMEO-II & $10 \%$ & $2.38 \pm 0.02$ & $2.30 \pm 0.02^{b}$ & $2.21 \pm 0.02^{\mathrm{ab}}$ & 3.36 & 7.14 \\
\hline VI & CMEO-II & $20 \%$ & $2.41 \pm 0.02$ & $2.17 \pm 0.02^{\mathrm{ab}}$ & $1.90 \pm 0.05^{\mathrm{ab}}$ & 9.96 & 21.16 \\
\hline VII & CMEO-I & $5 \%$ & $2.32 \pm 0.03^{a}$ & $2.29 \pm 0.03^{b}$ & $2.21 \pm 0.02^{\mathrm{ab}}$ & 1.29 & 4.74 \\
\hline VIII & CMEO-I & $10 \%$ & $2.26 \pm 0.02^{\mathrm{ab}}$ & $2.20 \pm 0.02^{\mathrm{ab}}$ & $2.15 \pm 0.03^{a b}$ & 2.65 & 4.87 \\
\hline IX & CMEO-I & $20 \%$ & $2.27 \pm 0.02^{\mathrm{a}}$ & $2.08 \pm 0.03 \mathrm{a}^{\mathrm{b}}$ & $1.90 \pm 0.03^{\mathrm{ab}}$ & 8.37 & 16.3 \\
\hline$x$ & Control & - & $2.40 \pm 0.02$ & $2.33 \pm 0.01$ & $2.32 \pm 0.01$ & 2.92 & 3.33 \\
\hline XI & Ibuprofen & $40 \mathrm{mg} / \mathrm{kg}$ b. wt. & $2.34 \pm 0.01^{a}$ & $1.73 \pm 0.02^{a}$ & $1.47 \pm 0.02^{\mathrm{a}}$ & 26.07 & 37.17 \\
\hline
\end{tabular}

${ }^{\mathrm{a}}=$ Significant $(p<0.05)$ as compared to control, ${ }^{\mathrm{b}}=$ Significant $(p<0.05)$ as compared to Ibuprofen. $\%=$ Percent reduction in paw volume at different times.

\subsubsection{Formaldehyde-Induced Inflammatory Activity}

CMEO-II, CMLEO, and CMEO-I resulted in moderate inhibition in paw volume compared to ibuprofen. CMEO-II revealed the greatest inhibition in paw volume $\left(2.23 \mathrm{~mm}^{3}\right.$ on day 1 and $2.20 \mathrm{~mm}^{3}$ on day 10), followed by CMLEO $\left(2.3 \mathrm{~mm}^{3}\right.$ on day 1 and $2.22 \mathrm{~mm}^{3}$ on day 10) and CMEO-I (2.26 $\mathrm{mm}^{3}$ on day 1 and $2.24 \mathrm{~mm}^{3}$ on day 10) at $20 \%$ dose level. The inhibition property was observed in a dose-dependent manner (Table 4). 
Table 4. Effect of essential oils from C. macrophylla on formalin-induced mice paw edema.

\begin{tabular}{|c|c|c|c|c|c|c|c|c|c|c|c|c|c|}
\hline \multirow{2}{*}{ Group } & \multirow{2}{*}{ Treatment } & \multirow{2}{*}{ Dose } & \multicolumn{11}{|c|}{ Volume of Paw Edema (in $\mathrm{mm}^{3}$ ) } \\
\hline & & & 0 Day & 1 Day & 2 Day & 3 Day & 4 Day & 5 Day & 6 Day & 7 Day & 8 Day & 9 Day & 10 Day \\
\hline I & CMLEO & $5 \%(0.2 \mathrm{~mL})$ & $2.28 \pm 0.02$ & $2.36 \pm 0.02 \mathrm{ab}$ & $2.37 \pm 0.04^{b}$ & $2.42 \pm 0.04^{b}$ & $2.41 \pm 0.04^{b}$ & $2.40 \pm 0.04^{b}$ & $2.40 \pm 0.04^{b}$ & $2.39 \pm 0.04^{b}$ & $2.39 \pm 0.03^{b}$ & $2.36 \pm 0.03^{b}$ & $2.36 \pm 0.04^{b}$ \\
\hline II & CMLEO & $10 \%(0.2 \mathrm{~mL})$ & $2.23 \pm 0.03$ & $2.26 \pm 0.02 \mathrm{ab}$ & $2.31 \pm 0.03^{b}$ & $2.35 \pm 0.04^{\mathrm{a}}$ & $2.34 \pm 0.03^{b}$ & $2.32 \pm 0.03^{b}$ & $2.32 \pm 0.03^{\mathrm{b}}$ & $2.31 \pm 0.03^{\mathrm{b}}$ & $2.31 \pm 0.03^{\mathrm{b}}$ & $2.31 \pm 0.03^{b}$ & $2.30 \pm 0.03^{\mathrm{b}}$ \\
\hline III & CMLEO & $20 \%(0.2 \mathrm{~mL})$ & $2.23 \pm 0.02$ & $2.25 \pm 0.02^{\mathrm{ab}}$ & $2.29 \pm 0.02^{b}$ & $2.30 \pm 0.04^{\mathrm{a}}$ & $2.29 \pm 0.04^{\mathrm{ab}}$ & $2.27 \pm 0.03^{\mathrm{a}}$ & $2.26 \pm 0.03 \mathrm{ab}$ & $2.25 \pm 0.02^{\mathrm{ab}}$ & $2.24 \pm 0.02^{\mathrm{a}}$ & $2.22 \pm 0.02^{a}$ & $2.22 \pm 0.02^{b}$ \\
\hline IV & CMEO -II & $5 \%(0.2 \mathrm{~mL})$ & $2.27 \pm 0.03$ & $2.30 \pm 0.02 \mathrm{ab}$ & $2.36 \pm 0.04^{b}$ & $2.40 \pm 0.05 \mathrm{ab}$ & $2.39 \pm 0.05^{b}$ & $2.38 \pm 0.05^{b}$ & $2.38 \pm 0.04 \mathrm{~b}$ & $2.38 \pm 0.03^{b}$ & $2.37 \pm 0.03^{b}$ & $2.36 \pm 0.03^{b}$ & $2.36 \pm 0.03^{a}$ \\
\hline $\mathrm{V}$ & CMEO-II & $10 \%(0.2 \mathrm{~mL})$ & $2.24 \pm 0.03$ & $2.27 \pm 0.02 \mathrm{ab}$ & $2.34 \pm 0.04^{b}$ & $2.38 \pm 0.04 \mathrm{ab}$ & $2.37 \pm 0.04^{b}$ & $2.36 \pm 0.03^{b}$ & $2.35 \pm 0.03^{b}$ & $2.33 \pm 0.03^{b}$ & $2.32 \pm 0.02^{b}$ & $2.31 \pm 0.02^{b}$ & $2.30 \pm 0.02 \mathrm{~b}$ \\
\hline VI & CMEO-II & $20 \%(0.2 \mathrm{~mL})$ & $2.23 \pm 0.02$ & $2.24 \pm 0.02 \mathrm{ab}$ & $2.26 \pm 0.02^{\mathrm{a}}$ & $2.28 \pm 0.03^{\mathrm{a}}$ & $2.26 \pm 0.03^{\mathrm{a}}$ & $2.25 \pm 0.02^{\mathrm{a}}$ & $2.24 \pm 0.02 \mathrm{ab}$ & $2.24 \pm 0.02 \mathrm{ab}$ & $2.22 \pm 0.03^{\mathrm{a}}$ & $2.21 \pm 0.02^{a}$ & $2.20 \pm 0.03^{a}$ \\
\hline VII & CMEO-I & $5 \%(0.2 \mathrm{~mL})$ & $2.28 \pm 0.02$ & $2.29 \pm 0.02 \mathrm{ab}$ & $2.37 \pm 0.03^{b}$ & $2.42 \pm 0.04^{b}$ & $2.41 \pm 0.03^{\mathrm{b}}$ & $2.41 \pm 0.03^{\mathrm{b}}$ & $2.41 \pm 0.03^{\mathrm{b}}$ & $2.41 \pm 0.02^{\mathrm{b}}$ & $2.41 \pm 0.02^{b}$ & $2.41 \pm 0.02^{b}$ & $2.40 \pm 0.02^{b}$ \\
\hline VIII & CMEO-I & $10 \%(0.2 \mathrm{~mL})$ & $2.26 \pm 0.03$ & $2.29 \pm 0.02^{\mathrm{ab}}$ & $2.32 \pm 0.03^{b}$ & $2.36 \pm 0.04^{\mathrm{a}}$ & $2.35 \pm 0.03^{b}$ & $2.35 \pm 0.03^{\mathrm{b}}$ & $2.34 \pm 0.02^{b}$ & $2.33 \pm 0.03^{b}$ & $2.35 \pm 0.03^{b}$ & $2.33 \pm 0.03^{b}$ & $2.33 \pm 0.03^{b}$ \\
\hline IX & CMEO-I & $20 \%(0.2 \mathrm{~mL})$ & $2.26 \pm 0.02$ & $2.27 \pm 0.02 \mathrm{ab}$ & $2.29 \pm 0.03^{b}$ & $2.31 \pm 0.03^{\mathrm{a}}$ & $2.30 \pm 0.02 \mathrm{ab}$ & $2.29 \pm 0.02 \mathrm{ab}$ & $2.27 \pm 0.01 \mathrm{ab}$ & $2.27 \pm 0.02 \mathrm{ab}$ & $2.25 \pm 0.02 \mathrm{ab}$ & $2.24 \pm 0.02^{a}$ & $2.24 \pm 0.02 \mathrm{ab}$ \\
\hline$x$ & Control & $(0.2 \mathrm{~mL})$ & $2.13 \pm 0.02$ & $2.17 \pm 0.04$ & $2.38 \pm 0.03$ & $2.52 \pm 0.04$ & $2.44 \pm 0.02$ & $2.39 \pm 0.01$ & $2.38 \pm 0.02$ & $2.38 \pm 0.01$ & $2.36 \pm 0.01$ & $2.36 \pm 0.02$ & $2.37 \pm 0.03$ \\
\hline XI & Ibuprofen & $10 \mathrm{mg} / \mathrm{kg}$ & $2.11 \pm 0.02$ & $2.13 \pm 0.02^{\mathrm{a}}$ & $2.19 \pm 0.01^{\mathrm{a}}$ & $2.27 \pm 0.01^{\mathrm{a}}$ & $2.21 \pm 0.02^{\mathrm{a}}$ & $2.19 \pm 0.01^{\mathrm{a}}$ & $2.15 \pm 0.01^{\mathrm{a}}$ & $2.16 \pm 0.01^{a}$ & $2.17 \pm 0.01^{\mathrm{a}}$ & $2.19 \pm 0.01^{b}$ & $2.15 \pm 0.02^{a}$ \\
\hline
\end{tabular}

${ }^{\mathrm{a}}=$ Significant $(p<0.05)$ as compared to control, ${ }^{\mathrm{b}}=$ Significant $(p<0.05)$ as compared to Ibuprofen. 


\subsection{Analgesic Activity}

CMEO-II, CMLEO, and CMEO-I showed significant analgesic activity with 35.33\%, 30.04\%, and $25.72 \%$ inhibition at $20 \%$ dose level, respectively, compared to the standard drug, ibuprofen, which inhibited $43.99 \%$ (Table 5). Prostaglandins have been reported to enhance inflammation and pain by increasing capillary permeability [29]. An analgesic substance reduces the number of writhings due to pain. It has been reported that analgesic drugs inhibit the synthesis of prostaglandins [30]. It can be inferred that the EOs of $C$. macophylla are responsible for the reduction of prostaglandin synthesis and exhibit analgesic properties.

Table 5. Effect of essential oils from C. macophylla on acetic acid induced writhing in mice.

\begin{tabular}{cccccc}
\hline Group & Treatment & Doses & Writhing Counts & \% Writhings & Inhibition (\%) \\
\hline I & CMLEO & $5 \%$ & $115.83 \pm 8.06^{\mathrm{ab}}$ & 83.53 & 16.47 \\
II & CMLEO & $10 \%$ & $107.00 \pm 4.52^{\mathrm{ab}}$ & 77.16 & 22.84 \\
III & CMLEO & $20 \%$ & $95.00 \pm 9.01^{\mathrm{ab}}$ & 69.95 & 31.49 \\
IV & CMEO -II & $5 \%$ & $112.33 \pm 5.28^{\mathrm{ab}}$ & 81 & 18.99 \\
V & CMEO-II & $10 \%$ & $104.33 \pm 7.09^{\mathrm{ab}}$ & 75.24 & 24.76 \\
VI & CMEO-II & $20 \%$ & $85.33 \pm 7.74^{\mathrm{a}}$ & 61.53 & 38.46 \\
VII & CMEO-I & $5 \%$ & $119.67 \pm 7.09^{\mathrm{ab}}$ & 86.3 & 13.7 \\
VIII & CMEO-I & $10 \%$ & $111.67 \pm 6.12^{\mathrm{ab}}$ & 80.53 & 19.47 \\
IX & CMEO-I & $20 \%$ & $103.00 \pm 4.86^{\mathrm{ab}}$ & 74.28 & 25.72 \\
X & Control & - & $138.67 \pm 5.75$ & - & - \\
XI & Ibuprofen & $40 \mathrm{mg} / \mathrm{kg}$ b. wt. & $77.67 \pm 6.86^{\mathrm{a}}$ & 56.01 & 43.99 \\
\hline \multicolumn{7}{c}{ a } & Significant $(p<0.05)$ as compared to control, ${ }^{\mathrm{b}}=$ Significant $(p<0.05)$ as compared to Ibuprofen.
\end{tabular}

\subsection{Antipyretic Activity}

All the oils revealed significant antipyretic activity. Yeast significantly induced pyrexia by increasing rectal temperature $18 \mathrm{~h}$ after injection. The reduction in temperature was observed up to $3 \mathrm{~h}$. A maximum reduction in pyrexia of $1.05^{\circ} \mathrm{C}(96.33 \%)$ was observed in paracetamol-treated group up to $24 \mathrm{~h}$. The uniform fall in temperature up to $24 \mathrm{~h}$ was observed by increasing the dose (Table 6). It has been reported in previous studies that the lipid per oxidation process is enhanced by increasing body temperature [31].

Infection in the body is a cause of fever or other diseased states like tissue damage, inflammation, and graft rejection etc. [32]. Regulation of body temperature requires equilibrium between the production and dissipation of heat. The present study exhibited significant antipyretic properties of EOs on brewer's yeast-induced pyrexia in mice. The antipyretic activity of EOs may be due to interference on the biosynthesis of prostaglandins. The result of this study revealed that $C$. macrophylla can be beneficial to treat inflammations, pain, and fever. These activities might be due to presence of a complex mixture of terpenoids.

The essential oil of C. macrophylla showed activities in various degrees against inflammation, pain, and fever. According to the research, higher levels of prostaglandin, particularly PGE2, produce inflammation, pain, and fever because of cyclooxygenase activation [33]. As a result, we suppose that some active constituents of the essential oils could inhibit cyclooxygenase activity. It has been reported that the carrageenan-induced paw edema in rats is susceptible to cyclooxygenase (COX) inhibitors. These have been used as non-steroidal anti-inflammatory agents and are also suitable for assessing the anti-oedematous effects of natural products [34,35]. 
Table 6. Effect of essential oils from C. macrophylla on brewer's yeast-induced pyrexia in mice.

\begin{tabular}{|c|c|c|c|c|c|c|c|c|c|c|}
\hline \multirow[b]{2}{*}{ Group } & \multirow[b]{2}{*}{ Treatment } & \multirow[b]{2}{*}{ Dose } & \multicolumn{2}{|c|}{ Body Temperature $\left({ }^{\circ} \mathrm{C}\right)$} & \multicolumn{3}{|c|}{ Body Temperature After Administration of Drug $\left({ }^{\circ} \mathrm{C}\right)$} & \multicolumn{3}{|c|}{$\%$ Reduction in Body Temperature } \\
\hline & & & $\begin{array}{c}\text { Before Injection } \\
\text { of Yeast }\end{array}$ & $\begin{array}{c}\text { After } 18 \mathrm{~h} \text { of } \\
\text { Yeast Injection }\end{array}$ & $1 \mathrm{~h}$ & $3 \mathrm{~h}$ & $24 \mathrm{~h}$ & $1 \mathrm{~h}$ & $3 \mathrm{~h}$ & $24 \mathrm{~h}$ \\
\hline I & CMLEO & $5 \%(0.2 \mathrm{~mL})$ & $37.57 \pm 0.05$ & $38.57 \pm 0.04$ & $38.29 \pm 0.03^{b}$ & $38.18 \pm 0.04^{\mathrm{ab}}$ & $38.13 \pm 0.03^{b}$ & 28 & 39 & 44.00 \\
\hline II & CMLEO & $10 \%(0.2 \mathrm{~mL})$ & $37.47 \pm 0.03$ & $38.49 \pm 0.03^{b}$ & $38.15 \pm 0.03^{\mathrm{ab}}$ & $38.01 \pm 0.04^{\mathrm{ab}}$ & $37.94 \pm 0.04{ }^{\mathrm{ab}}$ & 33.33 & 47.05 & 53.92 \\
\hline III & CMLEO & $20 \%(0.2 \mathrm{~mL})$ & $37.56 \pm 0.02^{\mathrm{a}}$ & $38.58 \pm 0.04$ & $37.99 \pm 0.03^{a b}$ & $37.86 \pm 0.04^{\mathrm{ab}}$ & $37.77 \pm 0.05^{\mathrm{ab}}$ & 57.84 & 70.59 & 79.41 \\
\hline IV & CMEO-II & $5 \%(0.2 \mathrm{~mL})$ & $37.55 \pm 0.03$ & $38.56 \pm 0.03$ & $38.27 \pm 0.02^{b}$ & $38.12 \pm 0.03^{a b}$ & $38.08 \pm 0.03^{a b}$ & 28.71 & 43.56 & 47.52 \\
\hline $\mathrm{V}$ & CMEO-II & $10 \%(0.2 \mathrm{~mL})$ & $37.49 \pm 0.04$ & $38.51 \pm 0.03$ & $38.14 \pm 0.04^{\mathrm{ab}}$ & $37.97 \pm 0.04^{\mathrm{ab}}$ & $37.90 \pm 0.04^{a b}$ & 36.27 & 52.94 & 59.8 \\
\hline VI & CMEO-II & $20 \%(0.2 \mathrm{~mL})$ & $37.51 \pm 0.04$ & $38.55 \pm 0.03$ & $37.89 \pm 0.04^{a b}$ & $37.73 \pm 0.02 \mathrm{ab}$ & $37.63 \pm 0.03^{a}$ & 63.46 & 78.85 & 88.46 \\
\hline VII & CMEO-I & $5 \%(0.2 \mathrm{~mL})$ & $37.48 \pm 0.03$ & $38.46 \pm 0.03^{b}$ & $38.19 \pm 0.03^{a b}$ & $38.12 \pm 0.04^{a b}$ & $38.06 \pm 0.04^{\mathrm{ab}}$ & 27.55 & 34.69 & 40.82 \\
\hline VIII & CMEO-I & $10 \%(0.2 \mathrm{~mL})$ & $37.52 \pm 0.02$ & $38.53 \pm 0.03$ & $38.20 \pm 0.04^{a b}$ & $38.07 \pm 0.04^{\mathrm{ab}}$ & $38.00 \pm 0.05^{\mathrm{ab}}$ & 32.67 & 45.54 & 52.47 \\
\hline IX & CMEO-I & $20 \%(0.2 \mathrm{~mL})$ & $37.49 \pm 0.02$ & $38.54 \pm 0.02$ & $37.97 \pm 0.02^{a b}$ & $37.87 \pm 0.02^{a b}$ & $37.76 \pm 0.05^{a b}$ & 54.28 & 63.81 & 74.29 \\
\hline$x$ & Control & $(0.2 \mathrm{~mL})$ & $37.46 \pm 0.02$ & $38.50 \pm 0.03$ & $38.36 \pm 0.04$ & $38.30 \pm 0.03$ & $38.22 \pm 0.03$ & 13.46 & 19.23 & 26.92 \\
\hline XI & Paracetamol & $33.0 \mathrm{mg} / \mathrm{kg}$ & $37.50 \pm 0.03$ & $38.59 \pm 0.04^{a}$ & $37.75 \pm 0.04^{\mathrm{a}}$ & $37.61 \pm 0.03^{a}$ & $37.54 \pm 0.04^{\mathrm{a}}$ & 77.06 & 89.91 & 96.33 \\
\hline
\end{tabular}




\subsection{Acute Toxicity}

Essential oils from parts of $C$. macrophylla neither cause any changes in behavior nor any death of mice under experimentation during the period of observation. It was thus considered that the EOs were practically non-toxic.

\section{Conclusions}

The EOs from C. macrophylla showed a qualitative and quantitative make-up of constituents. The oils also showed different pharmacological activities. From the results, it could be inferred that the essential oils might be used as drugs for treatment of inflammation, fever, and pain in traditional systems of medicine with scientific knowledge. Clinically, this herb can be a good source of herbal medicine for the treatment of diseases indigenously. The study will also help to generate a database of species which can be exploited scientifically and judiciously in the future by local people and so that ecological balance is maintained.

Acknowledgments: We are highly thankful to Jawahr Lal Neharu University, New Delhi for Gas chromatography and gas chromatography/mass spectrometry facilities. Thanks are also due to Govind Ballabh Pant University of Agriculture and Technology, Pantnagar, India for providing necessary research facilities. Thanks to Dharmandra Singh Rawat, plant taxonomist for authenticating the plant material.

Author Contributions: The first author, Mahesh Chandra persuade his Ph.D under the supervision of Rakesh Kumar Bachheti and Brij Bhushan, Om Prakash the second author co supervised him, part of work viz; antioxidant and GC/MS was conducted in Om Prakash's lab. Ravendra Kumar, Mahesh Kumar and Anil Kumar Pant helped in studying pharmacological and antioxidant activity work.

Conflicts of Interest: The authors declare that there is no conflict of interest.

\section{References}

1. Babu, C.R. Herbaceous Flora of Dehradun; PID Publication: New Delhi, India, 1977; pp. 395-396.

2. Yatato, S.; Chunyong, W.; Yanhua, C.; Wenyuan, L.; Feng, F.; Ning, X. Comparative analysis of three Callicarpa herbs using high performance liquid chromatography with diode array detector and electrospray ionization-trap mass spectrometry method. J. Pharm. Biom. Anal. 2013, 75, 239-247.

3. Megoneitso; Rao, R.R. Enthnobotanical studies in Nagaland-4. Sixty two medicinal plants used by the Agami Nagas. J. Econ. Tax. Bot. 1983, 4, 167-172.

4. Balodi, V. Introductory note on the enthnobotany of Gori Valley. J. Econ. Tax. Bot. 1998, 12, 453-455.

5. Singh, A.K.; Pawan, K.A. A diterpenoid from Callicarpa macrophylla. Phytochemistry 1994, 37, 587-588. [CrossRef]

6. Yadav, V.; Jayalakshmi, S.; Patra, A.; Singla, P.K. Investigation of Analgesic \& Anti-Pyretic Potentials of Callicarpa macrophylla Vahl. Leaves Extracts. Int. J. Med. Mol. Med. 2012, 3, 1-7.

7. Yadav, V.; Jayalakshmi, S.; Singh, R.K.; Patra, A. Preliminary Assessment of Anti-Inflammatory Activity of Callicarpa macrophylla Vahl. Leaves Extracts Indo-Global. J. Pharm. Sci. 2011, 1, 219-222.

8. Mozaina, K.; Mario, R.T.; Franck, E.D.; Stephen, O.D. Phytotoxicity and volatile constituents from leaves of Callicarpa japonica Thunb. Phytochemistry 2002, 61, 37-40.

9. Chandra, M.; Prakash, O.; Punetha, H.; Bhushan, B.; Bachetti, R.K.; Kumar, M.; Pant, A.K. An analgesic and anti-inflammatory activity of hydro-alcoholic leaves extracts of some indigenous herbs growing in Uttarakhand, India. Int. J. Inst. Pharm. Life Sci. 2015, 5, 116-123.

10. Singh, A.K.; Chanotiya, C.S.; Yadav, A.; Kalra, A. Volatile of Callicarpa macropylla: A rich source of selinene isomer. Nat. Prod. Commun. 2010, 5, 269-272. [PubMed]

11. Chatterjee, A.; Desmukh, S.K.; Chandrasekharan, S. Diterpenoid constituents of Callicarpa macrophylla Vahl: The structures and stereochemistry of calliterpenone and calliterpenonemonoacetate. Tetrahedron 1972, 28, 4319-4323. [CrossRef]

12. Adams, R.P. Identification of Essential Oil Components by Gas Chromatography/Mass Spectrometry, 4th ed.; Allured Business Media Publishing Corporation: Carol Stream, IL, USA, 2007.

13. Kumar, R.; Prakash, O.; Pant, A.K.; Isidorov, V.A.; Mathela, C.S. Chemical composition, antioxidant and myorelaxant activity of essential oils of Globba sessiliflora Sims. J. Essent. Oil Res. 2012, 24, 385-391. [CrossRef] 
14. Naskar, S.; Islam, A.; Mazumdar, U.K.; Saha, P.P.; Haldar, K.; Gupta, M. In vitro and in vivo antioxidant Potential of hydromethanolic extract of Phoenix dactylifera fruits. J. Sci. Res. 2010, 2, 144-157. [CrossRef]

15. Fu, W.; Chen, J.L.; Cai, Y.L.; Lei, Y.F.; Chen, L.M.; Pei, L.; Zhou, D.N.; Liang, X.F.; Ruan, J.L. Antioxidant, free radical scavenging, antiinflammatoryand hepatoprotective potential of the extract from Parathelypteris nipponica (Franch.etSav.) Ching. J. Ethnopharm. 2010, 130, 521-528. [CrossRef] [PubMed]

16. Olabinri, B.M.; Odedire, O.O.; Olaleye, M.T.; Adekunle, A.S.; Ehigie, L.O.; Olabinri, P.F. Evaluation of hydroxyl and nitric oxide radical scavenging activities. Res. J. Biol. Sci. 2010, 5, 102-105.

17. Chandra, M.; Parakash, O.; Bachheti, R.K.; Kumar, M.; Pant, A.K. Essential oil composition and pharmacological activities of Micromeria biflora (Buch.-Ham. Ex D. Don) Benth. collected from Uttarakhand region of India. J. Med. Res. 2013, 7, 2538-2544.

18. Italenti, A.; Ianaro, A.; Mancada, S.; Di Rosa, M. Modulation of acute inflammation by endogenous nitric oxide. Eur. J. Pharmacol. 1995, 211, 177-182. [CrossRef]

19. Oyaizu, M. Studies on product of browning reaction prepared from glucose amine Japan. J. Nutr. 1986, 44, 307-315.

20. Soares, J.R.; Dins, T.C.P.; Cunha, A.P.; Ameida, L.M. Antioxidant activity of some extracts of Thymus zygis. Free Rad. Res. 1997, 26, 469-478. [CrossRef]

21. Floyd, R.A. Nitric oxide and cancer development. J. Toxi. Pathol. 2007, 20, 77-92. [CrossRef]

22. Manjamalai, A.; Berlin Grace, V.M. Antioxidant Activity of Essential Oils from Wedelia chinensis (Osbeck) in vitro and in vivo Lung Cancer Bearing C57BL/6 Mice. Asian Pac. J. Cancer Prev. 2012, 13, 3065-3071. [CrossRef] [PubMed]

23. Mandal, P.; Mishra, T.K.; Ghosal, M. Free radical scavenging activity and phytochemical analysis in the leaf and stem of Drymaria diandra Glume. Indian J. Tuberc. 2009, 7, 80-84.

24. Halliwell, B.; Gutteridge, J.M.C. Free radicals in biology and medicine. In Free Radicals, Ageing, and Disease; Clarendron Press: Oxford, UK, 1985; Volume 2, pp. 279-315.

25. Beauchamp, C.; Fridovich, I. Superoxide dismutase: Improved assays and an assay applicable to acrylamide gels. Anal. Biochem. 1971, 44, 276-277. [CrossRef]

26. Gutteridge, M.C. Reactivity of hydroxyl and hydroxyl-like radicals discriminated by release of thiobarbituric acid reactive material from deoxy sugars, nucleosides and benzoate. Biochem. J. 1984, 224, 761-767. [CrossRef]

27. Spencer, J.P.E.; Jenner, A.O.I. Aroma Intense oxidative DNA damage promoted by L-DOPA and its metabolites, implications for neurodegenerative disease. FEBS Lett. 1994, 353, 246-250. [CrossRef]

28. Sanchez, M.C.; Larrauri, J.A.; Saura, C.F. Free radical scavenging capacity and inhibition of lipid oxidation of wines, grape juices and related polyphenolic constituents. Food Res. Int. 1999, 32, 407-412. [CrossRef]

29. Zakaria, Z.A.; Gani, A.Z.D.F. Antinociceptive, anti-inflammatory, and antipyretic properties of an aqueous extract of Dicranopteris linearis leaves in experimental animal models. J. Nat. Med. 2008, 62, 179-187. [CrossRef] [PubMed]

30. Collier, H.D.J.; Dinnin, L.C.C.; Johnson, A.; Schneider, C. The abdominal response and its suppression by analgesic drugs in mouse. Br. J. Pharm. 1968, 32, 295-310. [CrossRef]

31. Brazezinska, S.E. Fever induced oxidative stress. The effect on thyroid status and the $S^{\prime}$ monodeiodinase activity protective role of selenium vitamin. Eur. J. Phys. Pharm. 2001, 52, 275-284.

32. Devi, B.P.; Boominathan, R.; Mandal, S.C. Evalution of antipyreticpotential of Cleome viscose Linn. (Capparidaceae) extract in rats. J. Ethnopharmacol. 2003, 87, 11-13.

33. Dannhardt, G.; Kiefer, W. Cyclooxygenase inhibitors-Current status and future prospects. Eur. J. Med. Chem. 2001, 36, 109-126. [CrossRef]

34. Rao, C.V.; Kartik, R.; Ojha, S.K.; Amresh Rao, G.M.M. Anti-inflammatory and antinociceptive activity of stem juice powder of Tinospora cordifolia Miers. in experimental animals. Hamdard Med. 2005, XLVIII, 102-106.

35. Adedapo, A.A.; Sofidiya, M.O.; Maphosa, V.; Moyo, B.; Masika, P.J.; Afolayan, A.J. Anti-inflammatory and analgesic activities of the aqueous extract of Cussonia paniculata stem Bark. Rec. Nat. Prod. 2008, 2, 46-53.

(C) 2017 by the authors. Licensee MDPI, Basel, Switzerland. This article is an open access article distributed under the terms and conditions of the Creative Commons Attribution (CC BY) license (http:/ / creativecommons.org/licenses/by/4.0/). 